\title{
Formation of Methotrexate Polyglutamates in Purified Myeloid Precursor Cells from Normal Human Bone Marrow
}

\author{
Shoichi Koizumi, Gregory A. Curt, Robert L. Fine, James D. Griffin, and Bruce A. Chabner \\ Clinical Pharmacology Branch, Division of Cancer Treatment, National Cancer Institute, Bethesda, Maryland 20205; \\ and Dana-Farber Cancer Institute, Boston, Massachusetts 02115
}

\begin{abstract}
Immature myeloid precursor cells were preferentially selected from normal human bone marrow by using immune rosette techniques that employed monoclonal antibodies against mature granulocytes, monocytes, $T$ and $B$ lymphocytes, and erythroid precursors (Mo5, M3, OKT3, B1, and EP1, respectively). We examined the formation, retention, and cytotoxic effects of methotrexate (MTX) polyglutamates (MTX-PGs) in these purified myeloid precursor cells. After 1- and 24-h exposures to MTX, with thymidine and deoxyinosine as rescue, the intracellular MTX-PG profile was examined by high-pressure liquid chromatography. Efflux patterns of MTX-PGs were also studied after additional 1- and 24-h incubations in drug-free media. Cytotoxic effects of retained MTX-PGs on bone marrow myeloid precursors were examined by colony formation in drug-free semisolid agar.

Normal myeloid precursor cells converted MTX to MTXPGs in a concentration- and time-dependent manner, preferentially retaining MTX-PGs with three to five glutamyl moieties. At low concentrations of MTX (1 $\mu \mathrm{M})$, MTX-PG formation was insufficient to maintain saturation of the target enzyme dihydrofolate reductase after removal of drug from the incubation medium, and there was no decrease in myeloid colony formation. At higher concentrations of MTX $(10 \mu \mathrm{M})$, formation of higher molecular weight polyglutamates was sufficient to allow for 24-h saturation of intracellular binding capacity after removal of extracellular drug and resulted in a 35\% reduction in the formation of colony-forming units in culture. Comparison of MTX metabolism in normal bone marrow cells and the MTX-sensitive HL-60 human leukemia cell line showed twofold greater PG formation by these tumor cells after 24-h exposure to 1 or $10 \mu M M T X$, and a marked ( $>30$-fold) increase in cytotoxicity for the HL-60 cells as compared with normal myeloid precursors, suggesting that the MTX polyglutamation may be important to its selective antitumor action.
\end{abstract}

\section{Introduction}

Methotrexate (2,4-diamino,10-methylpteroyl glutamic acid; MTX or MTX-Glu $)^{1}$ is a potent inhibitor of dihydrofolate

\footnotetext{
Address reprint requests to Dr. Chabner, National Cancer Institute. Received for publication 13 August 1984 and in revised form 5 November 1984.
}

1. Abbreviations used in this paper: CFU-C, colony-forming unit in culture; DHFR, dihydrofolate reductase; FCS, fetal calf serum; MEM$\mathrm{AB}$, Eagle's minimum essential medium containing $2.5 \%$ pooled

The Journal of Clinical Investigation, Inc. Volume 75, March 1985, 1008-1014 reductase (DHFR) and has shown consistent clinical antitumor activity $(1,2)$. Like the physiologic folate cofactors (3), MTX is converted by various tissues to poly- $\boldsymbol{\gamma}$-glutamyl derivatives containing two to five glutamyl residues (MTX-PGs); this metabolic pathway has been demonstrated to be operative in vivo in a variety of normal and malignant cells, including human erythrocytes (4) and liver (5), and murine intestinal mucosa and tumors (6-9), and in vitro in human fibroblasts (10) and bone marrow aspirates (11), L1210 murine leukemia cells (12), Ehrlich ascites tumor cells (13), and rat hepatocytes and hepatoma cells (14-16). In previous studies we have examined the formation, retention, and pharmacologic effects of MTX-PGs in human breast cancer cell lines, using a highly specific high-pressure liquid chromatography analytic system that allows precise identification of chain length of the MTX derivatives (17-19). These studies showed that the polyglutamate derivatives with two to five $\gamma$-linked glutamyl moieties (MTX-Glu ${ }_{2}$ to MTX-Glu $)_{5}$ are selectively retained by cells after removal of extracellular drug. The degree of retention of these derivatives correlates directly with glutamyl chain length. MTX-PG retention was shown to prolong the cytotoxic action of this drug. Furthermore, in three patient-derived small-cell lung cancer cell lines, MTX responsiveness was closely related to the ability of cells to accumulate and retain the longer glutamyl chain derivatives (MTX-Glu 3 , $-\mathrm{Glu}_{4}$, and $-\mathrm{Glu}_{5}$ ) in excess of intracellular binding capacity (20). Such higher molecular weight MTX-PGs have high affinity for DHFR and provide prolonged inhibition of DNA synthesis and cell growth.

Although there have been a number of studies of preferential retention of MTX-PGs in tumor cell lines, little is known about their formation and retention in normal human tissues. Using the mononuclear cell fraction from mouse bone marrow, Fabre et al. (21) found little evidence of MTX-PG formation after a 2-h incubation with $5 \mu \mathrm{M}$ MTX and no depression of myeloid colony formation (CFU-C). In further studies, Fry et al. (22) observed no evidence of MTX-PGs in mouse gastrointestinal epithelium after in vivo doses of $12 \mathrm{mg} / \mathrm{kg} \mathrm{MTX}$. In these studies, however, a purified population of the appropriate dividing cell was not examined. In the present study, we have examined the formation, retention, and cytotoxic effects of MTX-PGs in myeloid precursor cells (MPCs) purified from normal human bone marrow by using immune rosette techniques. These studies indicate that MPCs have limited capacity to form MTX-PGs, but do so in a drug concentrationdependent and time-dependent pattern. The retention of MTXPGs, especially higher molecular weight species (MTX-Glu $-\mathrm{Glu}_{4}$, and $-\mathrm{Glu}_{5}$ ), by normal MPCs as well as by the human promyelocytic cell line HL-60 correlates with the cytotoxicity of MTX toward colony-forming cells of the normal and malignant cell populations.

human $\mathrm{AB}$ serum; MNC, mononuclear cell; MPC, myeloid precursor cell; MTX, methotrexate; PG, polyglutamate; SRBC, sheep erythrocyte. 


\section{Methods}

Chemicals. $\left[3^{\prime}, 5^{\prime}, 9^{\prime}-{ }^{3} \mathrm{H}\right]-\mathrm{MTX}$ (sp act $20 \mathrm{Ci} / \mathrm{mmol}$ ) was purchased from Amersham Corp. (Arlington Heights, IL) and further purified by DEAE-cellulose chromatography with elution along a linear gradient of 0.1-0.4 M NH $\mathrm{MHO}_{3}$, pH 8.3 (18). Unlabeled MTX was obtained from the Drug Synthesis and Chemistry Branch, National Cancer Institute (Bethesda, MD) and purified by the same procedure. LGlutamine was obtained from Flow Laboratories (McLean, VA) and DEAE-Sephacell from Beckman Instruments, Inc. (Fullerton, CA). All other chemicals were of reagent grade and were purchased from either Fisher Scientific Co. (Pittsburgh, PA) or Sigma Chemical Co. (St. Louis, MO). Ficoll-Hypaque (Ficoll-Paque) was obtained from Pharmacia Fine Chemicals (Piscataway, NJ), and RPMI-1640 medium from Gibco Laboratories (Grand Island, NY). Folate-free RPMI-1640 medium was obtained from the National Institutes of Health Media Unit (Bethesda, MD). Phosphate-buffered saline (pH 7.2), Eagle's minimum essential medium (MEM), and McCoy's 5A medium were purchased from M. A. Bioproducts (Walkersville, MD), agar (BactoAgar) from Difco Laboratories (Detroit, MI), and colony-stimulating factor (CSF-Chugai) from Chugai Pharmaceutical Co., Ltd. (Tokyo, Japan). Fetal calf serum (FCS) was obtained from Biofluids, Inc. (Rockville, MD) and dialyzed as described previously (18). Pooled human AB serum was obtained from the National Institutes of Health Blood Bank (Bethesda, MD) and sheep erythrocytes (SRBCs) were obtained from the National Institutes of Health Animal Center (Rockville, MD). The human promyelocytic leukemia cell line HL-60 (23) was provided by Dr. Gerald Batist (National Cancer Institute, Bethesda, MD) and was grown in RPMI-1640 supplemented with 10\% FCS, 2 $\mathrm{mM}$ L-glutamine, penicillin $124 \mu \mathrm{g} / \mathrm{ml}$, and streptomycin $270 \mu \mathrm{g} / \mathrm{ml}$, under $5 \% \mathrm{CO}_{2}$ at $37^{\circ} \mathrm{C}$.

Monoclonal antibodies OKT3, B1, and M3 were purchased from Ortho Pharmaceutical Co. (Raritan, NJ), Coulter Immunology (Hialeah, FL), and Becton, Dickinson \& Co. Monoclonal Center Inc. (Mountain View, CA), respectively. Mo5 monoclonal antibody recognizes all myeloid cells (from promyelocytes to polymorphonuclear granulocytes) except myeloblasts, as well as mature monocytes (24). The EP1 monoclonal antibody recognizes erythroid precursor cells (25), and was provided by Dr. T. Papayannopoulou (University of Washington, Seattle, WA). Affinity-purified goat anti-rabbit $\operatorname{IgG}\left[\mathrm{F}\left(\mathrm{ab}^{\prime}\right)_{2}\right.$ fragment specific] antibody was obtained from Cappel Laboratories (Malvern, PA), and the $F\left(a^{\prime}\right)_{2}$ fragment of rabbit anti-mouse Ig (IgG + IgA + IgM) was purchased from Zymal Laboratory Inc. (San Francisco, CA).

Purification of MPCs. After obtaining informed consent, heparinized bone marrow samples were collected by aspiration from the posterior iliac crest of normal volunteers. The mononuclear cell (MNC) population was separated by Ficoll-Hypaque gradient centrifugation (1.070 $\mathrm{g} / \mathrm{ml}$ ) as described previously $(26,27)$ and was resuspended in MEM containing $2.5 \%$ pooled human $\mathrm{AB}$ serum (MEM-AB). In order to obtain a purified fraction of MPCs from normal human bone marrow MNCs, immune rosette techniques were used, based on the method of Griffin et al. (28). SRBCs were washed five times with $0.9 \% \mathrm{NaCl}$. $1 \mathrm{ml}$ of packed SRBCs was added to $1 \mathrm{ml} \mathrm{CrCl}{ }_{3} \cdot 6 \mathrm{H}_{2} \mathrm{O}(1 \mathrm{mg} / \mathrm{ml}$ in $0.9 \% \mathrm{NaCl})$ and $1 \mathrm{ml}$ goat anti-rabbit IgG $\left[\mathrm{F}\left(\mathrm{ab}^{\prime}\right)_{2}\right.$ fragment specific]. After gentle mixing for $7 \mathrm{~min}$ at $23^{\circ} \mathrm{C}$, Ig-coated SRBCs were washed five times with $0.9 \% \mathrm{NaCl}$. These cells were stored as a $10 \%$ suspension. Before use, coated SRBCs were pelleted and resuspended in an equal volume of $F\left(a^{\prime}\right)_{2}$ fragment of rabbit anti-mouse $\operatorname{Ig}(\mathrm{IgG}+\mathrm{IgA}$ + IgM)-specific antibody $(1 \mathrm{mg} / \mathrm{ml})$. After incubation at $4^{\circ} \mathrm{C}$ for 30 min, SRBCs were washed twice in MEM-AB medium, and used as a $10 \%$ suspension. Bone marrow MNCs, $0.5-1.0 \times 10^{8}$, were incubated with $1 \mathrm{ml}$ of MEM-AB medium containing a mixture of monoclonal antibodies OKT3, B1, M3, and Mo5 at the final dilution of 1:100 each, and EP1 at a dilution of $1: 500$, for $30 \mathrm{~min}$ at $4^{\circ} \mathrm{C}$. After washing, $10^{8}$ antibody-treated MNCs were mixed with $0.75 \mathrm{ml}$ of a $10 \% \mathrm{Ig}$ coated SRBC suspension to allow immune rosette formation. The mixture was pelleted $(300 \mathrm{~g}, 10 \mathrm{~min})$ and then incubated at $4^{\circ} \mathrm{C}$ for
$30 \mathrm{~min}$. After resuspending $5 \mathrm{ml}$ of the SRBC-MNC mixture in MEMAB medium, nonrosetting cells (including the immature myeloid precursors), which had not been recognized by the panel of monoclonal antibodies, were separated from the immune rosettes by Ficoll-Hypaque $(1.070 \mathrm{~g} / \mathrm{ml})$ gradient centrifugation at $400 \mathrm{~g}$ for $30 \mathrm{~min}$. Thus, $\mathrm{T}$ and B lymphocytes, mature granulocytes, monocytes, and erythroid precursors were selectively eliminated from the heterogeneous bone marrow aspirate population, resulting in an enriched fraction of myeloblasts and colony-forming cells. The purified MPCs were collected from the gradient by centrifugation and SRBCs remaining in the purified MPC fraction were lysed by addition of $1 \mathrm{ml}$ of a hypotonic buffer $(0.17 \mathrm{M}$ $\mathrm{NH}_{4} \mathrm{Cl}, 0.01 \mathrm{M} \mathrm{KHCO}_{3}, 0.0001 \mathrm{M}$ EDTA) for $5 \mathrm{~min}$.

Determination of MTX-PG synthesis and bound and free MTX levels in MPCs. In order to examine intracellular MTX-PG formation, $0.5-1.0 \times 10^{6}$ purified MPCs were incubated at a concentration of $10^{6}$ cells/ml in folate-free RPMI-1640 with $10 \%$ dialyzed FCS, $2 \mathrm{mM} \mathrm{L-}$ glutamine, and either 1 or $10 \mu \mathrm{M}\left[{ }^{3} \mathrm{H}\right] \mathrm{MTX}$. This incubation medium was further supplemented with $10 \mu \mathrm{M}$ thymidine and $10 \mu \mathrm{M}$ deoxyinosine. This medium containing rescue nucleosides protected myeloid precursor cells from the cytotoxic action of MTX. After 1 or $24 \mathrm{~h}$ of incubation, cells were harvested to determine total intracellular drug and metabolite levels. Drug bound to intracellular target enzyme and free drug were separated by DEAE-Sephacell chromatography as described previously (18). In some experiments, at the end of the 24$\mathrm{h}$ drug incubation, remaining cells were washed twice with $5 \mathrm{ml}$ of phosphate-buffered saline and resuspended in an equal volume of drug-free complete media and incubated at $37^{\circ} \mathrm{C}$ for an additional 1 or $24 \mathrm{~h}$ in order to determine drug efflux patterns. At each time point, cells were processed for intracellular polyglutamate formation by highpressure liquid chromatography as described previously (18). Drug levels were expressed as nanomoles of MTX/gram of protein as determined by the method of Lowry et al. (29).

$C F U-C$ assay for cytotoxicity studies. In order to determine the effects of retained drug on CFU-C formation, separate aliquots of 2 $\times 10^{5}$ purified MPCs were incubated for $24 \mathrm{~h}$ in complete media containing 1 or $10 \mu \mathrm{M}$ MTX with thymidine and deoxyinosine. After incubation, cells were washed twice in $5 \mathrm{ml}$ of PBS and resuspended in the initial volume. CFU-C assays were performed using a soft-agar method originally described by Pike and Robinson (30). Cells, 1-2 $\times 10^{4}$ per plate, were cultured in $0.3 \%$ agar in drug-free and rescuefree McCoy's 5A medium supplemented with $20 \%$ dialyzed FCS and $10 \%$ dialyzed and partially purified colony-stimulating factor from the conditioned medium of thyroid cancer cells (CSF-Chugai) (31). After $10 \mathrm{~d}$ of incubation at $37^{\circ} \mathrm{C}$ in a humidified atmosphere of $5 \% \mathrm{CO}_{2}$ in air, colonies ( $\geq 40$ cells) and clusters (8-39 cells) were enumerated using an inverted microscopy.

\section{Results}

Cell preparation. Treatment with the panel of monoclonal antibodies, followed by SRBC rosetting, reduced the number of mononuclear cells to $2.2 \pm 0.9 \%$ (mean $\pm 1 \mathrm{SD}$ ) of the number harvested. Marked changes in the population distribution were observed, as shown in Table I and Fig. 1. Mature granulocytes (from myelocytes through polymorphonuclear leukocytes) decreased from $43 \pm 15 \%$ of the initial bone marrow aspirate population to only $12 \pm 6 \%$ of the cells in the purified fraction. $\mathrm{T}$ and $\mathrm{B}$ lymphocytes, monocytes, and erythroid precursors were virtually eliminated. Most notably, immature myeloid cells, including undifferentiated blasts and promyelocytes, increased from $4 \pm 2 \%$ to $80 \pm 23 \%$ of the total cell population. These changes were associated with a 6- to 26-fold increase in cloning efficiency in the CFU-C assay. MTX uptake, polyglutamation, and retention studies were performed on this purified MPC population.

Intracellular MTX-PG formation. The uptake and retention 
Table I. Comparison of Normal Bone Marrow

Cells Before and After Treatment with a

Panel of Monoclonal Antibodies and Rosetting

\begin{tabular}{|c|c|c|}
\hline & Before treatment & $\begin{array}{l}\text { After treatment } \\
\left(\mathrm{OKT3}^{-}, \mathrm{B1}^{-}, \mathrm{M3}^{-} \text {, }\right. \\
\left.\mathrm{Mo5}^{-}, \mathrm{EP1}^{-}\right)\end{array}$ \\
\hline & $\%$ & $\%$ \\
\hline Blasts & $2 \pm 1$ & $68 \pm 15$ \\
\hline Promyelocytes & $2 \pm 1$ & $12 \pm 8$ \\
\hline Myelocytes & $5 \pm 1$ & $3 \pm 1$ \\
\hline Metamyelocytes & $19 \pm 9$ & $7 \pm 3$ \\
\hline Bands & $12 \pm 4$ & $2 \pm 1$ \\
\hline Polys & $7 \pm 5$ & $0 \pm 1$ \\
\hline Monocytes & $20 \pm 10$ & $3 \pm 2$ \\
\hline Lymphocytes & $20 \pm 9$ & $3 \pm 3$ \\
\hline Erythroid precursors & $13 \pm 5$ & $2 \pm 1$ \\
\hline $\begin{array}{l}\text { Nonspecific esterase- } \\
\text { positive cells }\end{array}$ & $18 \pm 2$ & $3 \pm 1$ \\
\hline $\begin{array}{l}\text { Peroxidase-positive } \\
\text { cells }\end{array}$ & $55 \pm 21$ & $26 \pm 14$ \\
\hline $\mathrm{T}^{+}$ & $18 \pm 2$ & $1 \pm 0.5$ \\
\hline $\mathrm{B}^{+}{ }^{+}$ & $1 \pm 0.5$ & $<0.5$ \\
\hline CFU-C & $85 \pm 34 / 10^{5}$ cells & $140 \pm 62 / 10^{4}$ cells \\
\hline
\end{tabular}

Anti-OKT3 and -B1 positive cells were determined by indirect immunofluorescence techniques. CFU-C colony formation was performed by a semisolid agar method. Each value is expressed as the mean \pm standard deviation of four separate experiments.

of MTX and its metabolism to PG forms were examined in MPCs in the presence of rescue nucleosides-thymidine and inosine-in order to prevent cytotoxic drug effects during this phase of the experiment. Cell counts of marrow preparations before and after 24-h drug incubation with 1 or $10 \mu \mathrm{M}$ MTX confirmed that there was no decrease in cell numbers during this period. The intracellular bound and free drug levels and the MTX polyglutamation profile in bone marrow MPCs were determined after 1 and $24 \mathrm{~h}$ of drug exposure and after 1 and

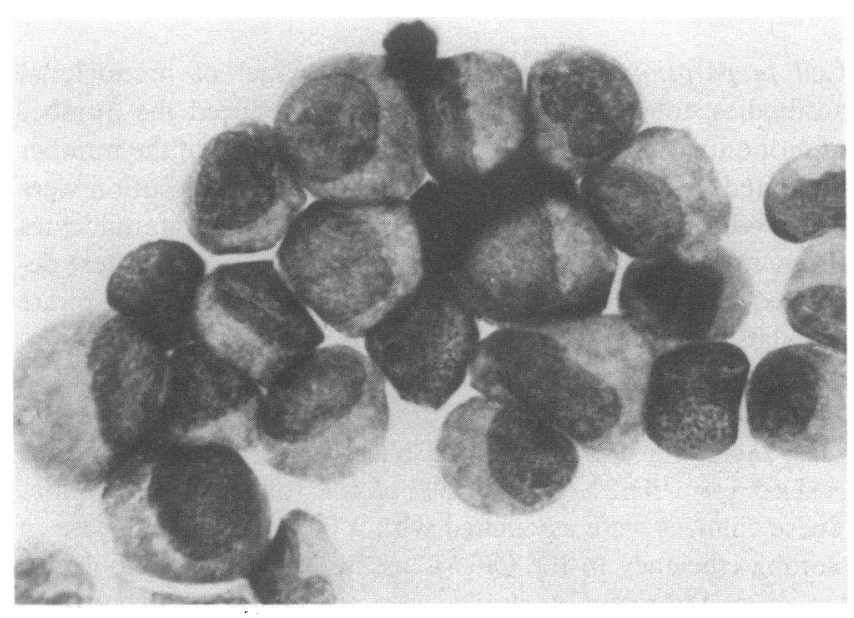

Figure 1. Separated bone marrow MPC population. These cells were selected by immunorosette techniques as described in Methods. 24-h efflux periods in drug-free media (Tables II and III). Drug levels at each time point are also expressed as percent saturation of intracellular binding capacity, as shown in Fig. 2. Intracellular drug accumulation was concentration and time dependent. After a 1-h exposure to either 1 or $10 \mu \mathrm{M}$ MTX, free intracellular drug levels in excess of DHFR were achieved. However, during this 1-h period of exposure, there was little PG formation and these metabolites constituted less than $30 \%$ of the intracellular antifolate pool. After a 24-h drug incubation, intracellular free drug levels were increased approximately threefold in comparison with $1-h$ levels, both at $1 \mu \mathrm{M}$ and at $10 \mu \mathrm{M}$ MTX. The increase in intracellular drug between 1 and $24 \mathrm{~h}$ was totally accounted for by the formation of MTXPGs. Total intracellular drug after 24-h exposure was $12.52 \pm 3.78 \mathrm{nmol} / \mathrm{g}$ in $1 \mu \mathrm{M} \mathrm{MTX}$, whereas after an identical period of exposure to $10 \mu \mathrm{M}$ MTX, total intracellular drug was 42.67 $\pm 12.99 \mathrm{nmol} / \mathrm{g}$. Metabolism of MTX to PG derivatives MTX-Glu ${ }_{2}$ through - $\mathrm{Glu}_{5}$ was drug concentration dependent, the increased intracellular drug levels at higher doses being largely accounted for by a threefold increase in MTXPGs $(30 \mathrm{nmol} / \mathrm{mg}$ at $10 \mu \mathrm{M}$ vs. $10 \mathrm{nmol} / \mathrm{g}$ at $1 \mu \mathrm{M}$ MTX).

We next determined the efflux pattern of MTX-PGs from MPCs. Cells were first incubated with 1 or $10 \mu \mathrm{M}$ MTX for $24 \mathrm{~h}$ and were then resuspended in drug-free medium. After incubation of cells for $1 \mathrm{~h}$ in drug-free medium (1-h efflux, Table III), total intracellular drug levels decreased. This decrease in intracellular drug was due predominantly to efflux of MTX $\left(-G_{1}\right)$. Polyglutamate metabolites with three or more glutamyl moieties were preferentially retained in the absence of free extracellular drug. As shown in Fig. $2 \mathrm{~B}$, after $24 \mathrm{~h}$ of efflux, little MTX-Glu ${ }_{1}$ and MTX-Glu ${ }_{2}$ were retained intracellularly, although sufficient MTX-Glu 3 , -Glu entially retained to continue to saturate intracellular binding capacity. Table III shows that after $24 \mathrm{~h}$ of incubation in 10 $\mu \mathrm{M}$ MTX and $24 \mathrm{~h}$ of efflux into drug-free medium, $\sim 85 \%$ of the remaining intracellular drug was accounted for by the higher molecular weight PG species. Only 5\% of drug originally present as parent compound after $24 \mathrm{~h}$ of incubation was retained after the 24-h efflux period; $25 \%$ of $\mathrm{Glu}_{2}$ was retained; $40 \%$ of $\mathrm{Glu}_{3} ; 70 \%$ of $\mathrm{Glu}_{4}$; and nearly $100 \%$ of $\mathrm{Glu}_{5}$. Free drug in excess of that bound to DHFR $(12.73 \pm 4.11 \mathrm{nM} / \mathrm{g}$ remained after 24-h incubation in drug-free media. However, after $24 \mathrm{~h}$ of exposure to $1 \mu \mathrm{M}$ MTX, only small amounts of high molecular weight PGs were formed by bone marrow MPCs (Table II). After $24 \mathrm{~h}$ of efflux in drug-free media, only $2.95 \pm 1.37 \mathrm{nmol} / \mathrm{g}$ of free drug were retained.

Cytotoxic effects of MTX-PGs on CFU-C formation. We next sought to determine the cytotoxic effects of retained MTX-PGs on the myeloid colony-forming ability of the MPC fraction. Cells were exposed to either 1 or $10 \mu \mathrm{M}$ MTX in complete media for $24 \mathrm{~h}$ in the presence of rescue nucleosides, and were then assessed for CFU-C survival using a medium that contained dialyzed FCS without added purines or pyrimidines. 24-h exposure to $1 \mu \mathrm{M}$ MTX in the presence of rescue had no effect on subsequent CFU-C formation, whereas 24-h exposure to $10 \mu \mathrm{M}$ drug under the same conditions resulted in a significant reduction to $65.2 \pm 8.7 \%$ of control $(P<0.001)$ in CFU-C formation (Table IV).

$M T X-P G$ formation and cytotoxicity in $H L-60$ cell line. In order to determine whether MTX-PG formation is associated with prolonged cytotoxic effect in MTX-sensitive myloid tumor cells and to determine that the rosetting conditions had no 
Table II. Total Bound and Free Intracellular Drug and PG Profile in MPCs from Normal Human Bone Marrow*

\begin{tabular}{|c|c|c|c|c|c|c|c|c|}
\hline $\begin{array}{l}\text { Incubation } \\
\text { time }\end{array}$ & Total drug & Bound drug & Free drug & MTX & MTX-Glu & MTX-Glu & MTX-Glus & MTX-Glu \\
\hline & $\begin{array}{l}\text { nmol/g } \\
\text { protein }\end{array}$ & $\begin{array}{l}\text { nmol/g } \\
\text { protein }\end{array}$ & $\begin{array}{l}\text { nmol/g } \\
\text { protein }\end{array}$ & $\begin{array}{l}\text { nmol/g } \\
\text { protein }\end{array}$ & $\begin{array}{l}\text { nmol/g } \\
\text { protein }\end{array}$ & $\begin{array}{l}\text { nmol/g } \\
\text { protein }\end{array}$ & $\begin{array}{l}\text { nmol/g } \\
\text { protein }\end{array}$ & $\begin{array}{l}\text { nmol/g } \\
\text { protein }\end{array}$ \\
\hline $1(n=4)$ & $4.72 \pm 0.65$ & $1.25 \pm 0.29$ & $3.47 \pm 0.48$ & $3.74 \pm 0.62$ & $0.87 \pm 0.45$ & $0.11 \pm 0.13$ & 0 & 0 \\
\hline $24(n=5)$ & $12.52 \pm 3.78$ & $2.13 \pm 0.61$ & $10.39 \pm 3.54$ & $2.59 \pm 1.01$ & $2.58 \pm 0.98$ & $4.10 \pm 1.75$ & $2.25 \pm 1.06$ & $0.99 \pm 0.45$ \\
\hline \multicolumn{9}{|l|}{ 1-h efflux } \\
\hline$(n=3)$ & $10.83 \pm 8.42$ & $2.51 \pm 1.15$ & $8.32 \pm 7.28$ & $0.77 \pm 0.07$ & $1.85 \pm 0.92$ & $4.44 \pm 4.43$ & $2.60 \pm 2.18$ & $1.18 \pm 0.95$ \\
\hline \multicolumn{9}{|l|}{ 24-h efflux } \\
\hline$(n=5)$ & $5.38 \pm 2.21$ & $2.43 \pm 1.05$ & $2.95 \pm 1.37$ & $0.40 \pm 0.14$ & $0.86 \pm 0.47$ & $2.12 \pm 0.47$ & $1.29 \pm 0.70$ & $0.71 \pm 0.34$ \\
\hline
\end{tabular}

After 1- and 24-h incubations with $1 \mu \mathrm{M}\left[{ }^{3} \mathrm{H}\right] \mathrm{MTX}$ and after another 1 and $24 \mathrm{~h}$ in drug-free media, cell extracts of purified bone marrow MPCs $\left(1 \times 10^{6}\right)$ cells were assayed by high-pressure liquid chromatography for MTX-PGs. Bound and free compounds were separated by DEAE-Sephacell chromatography. Each value expresses mean \pm 1 SD. ${ }^{*}$ After exposure to $1 \mu \mathrm{M}\left[{ }^{3} \mathrm{H}\right] \mathrm{MTX}$ for 1 or $24 \mathrm{~h}$, with subsequent $1-$ or 24-h efflux in drug-free medium.

effect on MTX-PG formation and cytotoxicity, metabolic studies were performed using the human promyelocytic leukemia cell line HL-60. Identical results were obtained in experiments with or without the immune rosetting procedures. In comparison with bone marrow cells, two- to threefold greater levels of total intracellular drug $(23.92 \mathrm{nmol} / \mathrm{g})$ were achieved after 24-h incubation with $1 \mu \mathrm{M}\left[{ }^{3} \mathrm{H}\right] \mathrm{MTX}$ in the HL-60 cell line (Table V). Higher molecular weight PGs $\left(\mathrm{MTX}-\mathrm{Glu}_{3},-\mathrm{Glu}_{4}\right.$, and $-\mathrm{Glu}_{5}$ ) were increased concomitantly (17.08 nmol/g as compared with $7.34 \mathrm{nmol} / \mathrm{g}$ in normal MPCs). After exposure of HL-60 cells to $1 \mu \mathrm{M}$ MTX and 24 h of efflux, sufficient higher molecular weight PGs were retained to saturate intracellular binding capacity (Table V), with an excess of $8.09 \mathrm{nmol} / \mathrm{g}$ of protein as free drug as compared with a free-drug level of only $2.95 \mathrm{nmol} / \mathrm{g}$ of protein in the bone marrow MPC (Table II). Data in Table V also show that the panel of monoclonal antibodies had no effect on the ability of HL-60 to form MTX-PGs.

The growth inhibition of colony formation of HL-60 cells after 24-h exposure to MTX is shown in Table VI. Cell numbers and viability, as determined by trypan blue exclusion, remained constant during the drug-exposure period itself, as cells were rescued from MTX cytotoxicity by exogenous thymidine and deoxyinosine. Consequently, any effect on cell growth noted thereafter in drug- and rescue-free medium represented the delayed cytotoxic effect of retained MTX-PGs. Even after exposure to $1 \mu \mathrm{M}$ MTX, a concentration that had no effect on CFU-C formation, marked (97\%) inhibition of HL-60 colony formation was observed.

\section{Discussion}

The present study demonstrates that normal bone marrow MPC form limited quantities of MTX-PGs in a concentrationand time-dependent pattern and that these metabolites are preferentially retained by myeloid precursors in direct proportion to PG chain length. At low MTX concentrations $(1 \mu \mathrm{M})$, only small amounts of higher molecular weight MTX-PGs were formed by MPCs, free-drug concentrations exceeded binding capacity by only $2.95 \mathrm{nmol} / \mathrm{g}$ of protein after removal of free drug, and there was no delayed effect on CFU-C colony formation when cells were resuspended in drug-free media. At high MTX concentrations $(10 \mu \mathrm{M})$, target enzyme in bone marrow MPC was saturated by retained, higher molecular weight MTX-PGs in a similar manner to HL-60 cells, and a $35 \%$ reduction in CFU-C formation was seen. The levels of

Table III. Total Bound and Free Intracellular Drug and PG Profile in MPCs from Normal Human Bone Marrow*

\begin{tabular}{|c|c|c|c|c|c|c|c|c|}
\hline $\begin{array}{l}\text { Incubation } \\
\text { time }\end{array}$ & Total drug & Bound drug & Free drug & MTX & MTX-Glu & MTX-Glu & MTX-Glus & MTX-Glus \\
\hline & $\begin{array}{l}\text { nmol/g } \\
\text { protein }\end{array}$ & $\begin{array}{l}\text { nmol/g } \\
\text { protein }\end{array}$ & $\begin{array}{l}\text { nmol/g } \\
\text { protein }\end{array}$ & $\begin{array}{l}\text { nmol/g } \\
\text { protein }\end{array}$ & $\begin{array}{l}\text { nmol/g } \\
\text { protein }\end{array}$ & $\begin{array}{l}\text { nmol/g } \\
\text { protein }\end{array}$ & $\begin{array}{l}\text { nmol/g } \\
\text { protein }\end{array}$ & $\begin{array}{l}\text { nmol/g } \\
\text { protein }\end{array}$ \\
\hline $1(n=4)$ & $15.24 \pm 4.78$ & $2.15 \pm 0.54$ & $13.09 \pm 4.39$ & $11.16 \pm 3.31$ & $3.50 \pm 1.76$ & $0.54 \pm 0.41$ & $0.03 \pm 0.06$ & 0 \\
\hline $24(n=9)$ & $42.47 \pm 12.99$ & $3.94 \pm 1.76$ & $38.52 \pm 12.05$ & $12.89 \pm 5.30$ & $6.88 \pm 6.07$ & $12.82 \pm 5.34$ & $7.30 \pm 2.43$ & $2.57 \pm 1.31$ \\
\hline 1-h efflux & & & & & & & & \\
\hline $\begin{array}{c}(n=4) \\
24-h \text { efflux }\end{array}$ & $38.14 \pm 12.85$ & $3.23 \pm 0.94$ & $34.91 \pm 11.92$ & $3.72 \pm 1.46$ & $6.82 \pm 2.78$ & $15.62 \pm 6.22$ & $8.75 \pm 3.60$ & $3.20 \pm 1.82$ \\
\hline$(n=4)$ & $16.23 \pm 4.65$ & $3.50 \pm 1.43$ & $12.73 \pm 4.11$ & $0.67 \pm 0.37$ & $1.62 \pm 0.31$ & $5.50 \pm 1.97$ & $5.28 \pm 1.63$ & $3.17 \pm 2.10$ \\
\hline
\end{tabular}

After 1- and 24-h incubations with $10 \mu \mathrm{M}\left[{ }^{3} \mathrm{H}\right] \mathrm{MTX}$ and after another 1 and $24 \mathrm{~h}$ in drug-free media, cells extracts of purified bone marrow MPCs were assayed by high-pressure liquid chromatography for MTX-PGs. Bound and free compounds were separated by DEAE-Sephacell chromatography. Each value expresses mean $\pm 1 \mathrm{SD}$. ${ }^{*}$ After exposure to $10 \mu \mathrm{M}\left[{ }^{3} \mathrm{H}\right] \mathrm{MTX}$ for 1 or $24 \mathrm{~h}$, with subsequent 1 - or 24 -h efflux in drug-free medium. 


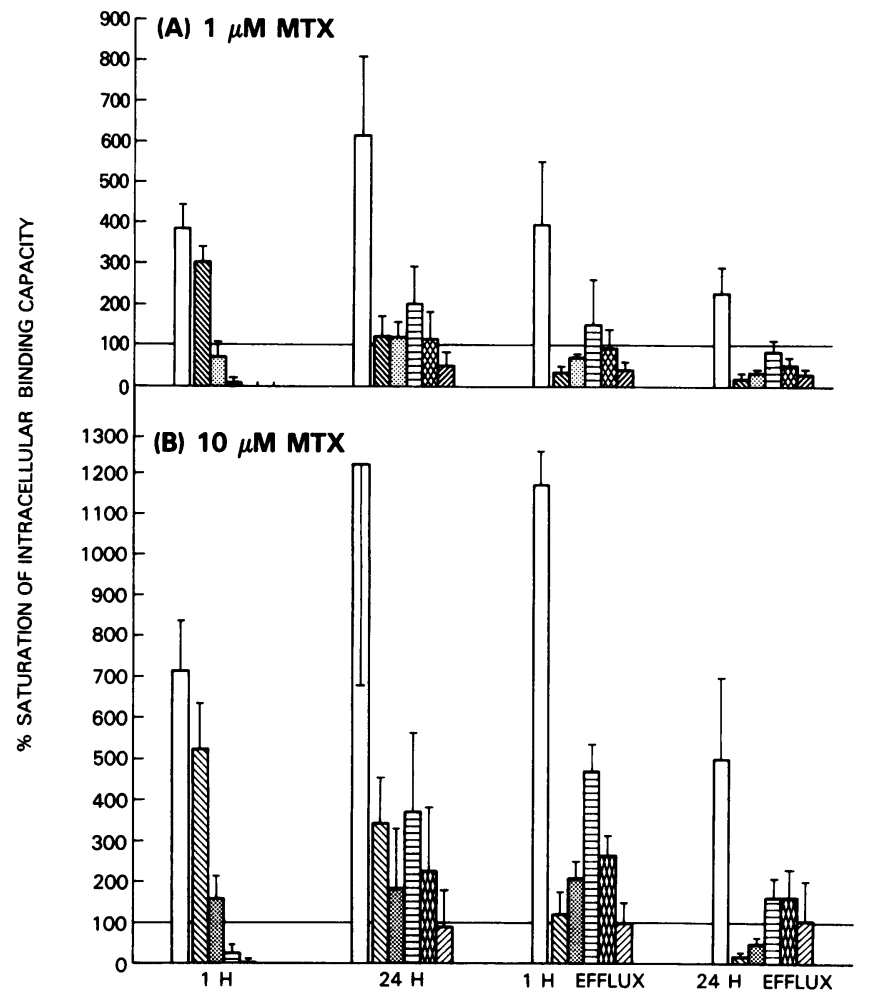

Figure 2. Total intracellular drug, $\square ;$ MTX, $₫ ;$ MTX-Glu ${ }_{2}$, $₫$; MTX$\mathrm{Glu}_{3}$, $\approx$; MTX-Glu, a; and MTX-Glu, a; expressed as percent saturation of intracellular binding capacity after incubation with 1 $\mu \mathrm{M}(A)$ or $10 \mu \mathrm{M}(B) \mathrm{MTX}$ for $1 \mathrm{~h}, 24 \mathrm{~h}$, and subsequent 1 and 24 $h$ efflux in drug-free media.

MTX-PGs in MPC were $37-48 \%$ of those in the HL-60 tumor cell line under identical conditions of exposure. A direct correlation between chain length and MTX-PG retention was found in both normal bone marrow MPC and promyelocytic leukemia cells. After 24-h exposure to $1 \mu \mathrm{M}$ MTX, HL-60 cells formed nearly twice the concentration of higher molecular

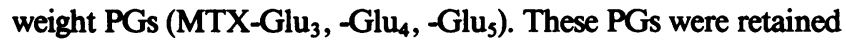
in the absence of free extracellular drug ( $8.09 \mathrm{nmol}$ of free

Table IV. MTX Inhibition of Bone Marrow CFU-C

\begin{tabular}{lll}
\hline MTX concentration & $\begin{array}{l}\text { No. of cells after 24-h } \\
\text { incubation with MTX }\end{array}$ & $\begin{array}{l}\text { CFU-C } \\
\text { (colonies + clusters) }\end{array}$ \\
\hline$\mu M$ & $\%$ control & $\%$ control \\
0 (control) & 100 & 100 \\
1 & $100.7 \pm 9.5$ & $99.1 \pm 15.6$ \\
10 & $99.7 \pm 15.9$ & $65.2 \pm 8.7$ \\
& & $(p<0.001)$
\end{tabular}

Purified MPCs were incubated for $24 \mathrm{~h}$ in medium containing the indicated concentration of MTX, $10 \mu \mathrm{M}$ thymidine, and $10 \mu \mathrm{M}$ deoxyinosine. After counting the number of viable cells by trypan blue dye exclusion, 1-2 $\times 10^{4}$ cells were then washed and plated in semisolid agar containing 20\% dialyzed FCS and 10\% dialyzed and partially purified colony-stimulating factor (31) in drug- and rescue-free medium. The number of CFU-Cs in the control group was 79 \pm 43 / $10^{4}$ cells. Each value represents the mean \pm 1 SD of six separate experiments. $\mathrm{drug} / \mathrm{mg}$ of protein at 24 -h efflux) and continued to saturate the binding capacity, leading to nearly complete suppression $(97 \%)$ of clonogenicity.

Although these studies provide evidence for limited capacity of early myeloid cells to form MTX-PGs, the correlation of MTX-PG formation with toxicity to CFU-C is speculative because the CFU-Cs constituted only $1.4 \%$ of the cells, despite the enrichment of this preparation. However, in view of the absence of MTX-delayed cytotoxicity at drug levels of $1 \mu \mathrm{M}$ and modest toxicity to CFU-C at $10 \mu \mathrm{M}$, it is likely that MTX-PG formation is either equal to or less than that of the overall MPC fraction examined in this study.

The results of the present studies may be compared with those previously reported for other human tumor cell lines. Our previous studies of human breast cancer cell lines showed considerable PG synthesis and delayed cytotoxicity in a MTXsensitive cell line even at a low MTX concentration $(2 \mu \mathrm{M})$ (18). After 24-h incubation, the level of total intracellular drug in the MCF-7 cell line reached $95.4 \mathrm{nmol} / \mathrm{g}$, and $55.4 \%(51.9$ $\mathrm{nmol} / \mathrm{g}$ ) of drug was in the form of MTX-PGs. Preferential retention of MTX-PGs was noted after an additional 24-h incubation in drug-free media. In contrast, a MTX-resistant breast cancer cell line (MDA) synthesized small amounts of MTX-PGs (4.06 $\mathrm{nmol} / \mathrm{g}$ ) under the same conditions of exposure. A similar close relationship between MTX-PG formation and sensitivity to MTX has been reported in a study of three small-cell lung cancer cell lines (20). Levels of MTX-PGs in normal bone marrow MPC are considerably lower, even at a high MTX concentration (10 $\mu \mathrm{M})$, than the levels of MTXPGs in the various MTX-sensitive tumor cell lines at 1-2 $\mu \mathrm{M}$ MTX. Thus, the selective effects of MTX on tumor cells as compared with bone marrow may be in part due to the limited capacity of myeloid precursors to form MTX-PGs. Additionally, a nearly twofold increase in DHFR binding capacity in MPC was noted after 24-h exposure to MTX. This fact might also be a significant factor contributing to the relative resistance of normal bone marrow cells to MTX.

The foregoing results may help to explain the selective effects of MTX for malignant cells versus bone marrow myeloid precursors. The inefficient formation of MTX-PGs by myeloid precursors at drug levels of $1 \mu \mathrm{M}$ or below (the usual range of concentrations achieved by other than highdose regimens), may explain the rapid recovery of DNA synthesis in bone marrow when extracellular drug levels fall below the critical threshold of $1 \times 10^{-8} \mathrm{M}$ (32). The recovery of DNA synthesis would be delayed in cells containing levels of MTX-PGs in excess of the DHFR binding capacity. Certainly factors other than MTX-PG formation influence cytotoxicity. These include drug transport, the level of DHFR, and the activity of thymidylate synthetase (2). The extreme sensitivity of HL-60 cells to MTX, as shown in the present study, is not solely explained by MTX-PG formation, in that the level of free intracellular PGs after 24-h exposure of cells to $1 \mu \mathrm{M}$ MTX was less than that found in MPCs after exposure to 10 $\mu \mathrm{M}$ drug, and yet this level was associated with $97 \%$ cytotoxicity of HL-60 cells, as compared with only a $35 \%$ reduction in CFU-C. Nonetheless, MTX-PG formation appears to be a necessary step for prolonging drug action in the absence of extracellular drug. A more detailed study of MTX metabolism and cytotoxicity in human tumor cells will be required in order to understand the importance of polyglutamation in determining drug effects in humans. 
Table V. Total, Bound, and Free Intracellular Drug and PG Profile in HL-60 Cells*

\begin{tabular}{|c|c|c|c|c|c|c|c|c|c|}
\hline $\begin{array}{l}\text { Incuba- } \\
\text { tion }\end{array}$ & Time & $\begin{array}{l}\text { Total } \\
\text { drug }\end{array}$ & $\begin{array}{l}\text { Bound } \\
\text { drug }\end{array}$ & $\begin{array}{l}\text { Free } \\
\text { drug }\end{array}$ & MTX & $\begin{array}{l}\text { MTX- } \\
\text { Glu }_{2}\end{array}$ & $\begin{array}{l}\text { MTX- } \\
\text { Glu }_{3}\end{array}$ & $\begin{array}{l}\text { MTX- } \\
\text { Glu }_{4}\end{array}$ & $\begin{array}{l}\text { MTX- } \\
\text { Glus }\end{array}$ \\
\hline$\mu M$ & $h$ & $\begin{array}{l}\text { nmol/g } \\
\text { protein }\end{array}$ & $\begin{array}{l}\text { nmol } / g \\
\text { protein }\end{array}$ & $\begin{array}{l}\text { nmol/g } \\
\text { protein }\end{array}$ & $\begin{array}{l}\text { nmol/g } \\
\text { protein }\end{array}$ & $\begin{array}{l}\text { nmol/g } \\
\text { protein }\end{array}$ & $\begin{array}{l}\text { nmol/g } \\
\text { protein }\end{array}$ & $\begin{array}{l}\text { nmol } / g \\
\text { protein }\end{array}$ & $\begin{array}{l}n \mathrm{nmol} / \mathrm{g} \\
\mathrm{protein}\end{array}$ \\
\hline 1.0 & 24 & 18.31 & 2.27 & 16.04 & 1.72 & 2.65 & 6.17 & 4.76 & 2.98 \\
\hline 1.0 & 24-h efflux & 11.47 & 3.38 & 8.09 & 0.13 & 0.54 & 3.72 & 4.20 & 2.89 \\
\hline 10 & 24 & 93.98 & 3.01 & 90.97 & 14.47 & 14.00 & 34.21 & 22.09 & 9.21 \\
\hline 10 & 24-h efflux & 20.97 & 3.00 & 17.97 & 0.94 & 1.38 & 7.00 & 6.90 & 4.72 \\
\hline
\end{tabular}

HL-60 cells were treated with five monoclonal antibodies and immunoglobulin-coated SRBCs in the same immune rosette techniques as bone marrow cells. After treatment, HL-60 cells were incubated with 1 or $10 \mu \mathrm{M}$ MTX for $24 \mathrm{~h}$ and for another $24 \mathrm{~h}$ in drug-free media. Separation of bound and free compounds and MTX polyglutamation profile were examined by the same methods as those in normal purified MPCs. Treatment with monoclonal antibodies had no effect on intracellular MTX polyglutamation or retention. See Methods for details. ${ }^{*}$ After exposure to 1 or $10 \mu \mathrm{M}$ MTX for $24 \mathrm{~h}$ and subsequent 24-h efflux in drug-free medium.

Poser et al. (8) examined MTX-PG formation in murine bone marrow, as did Fabre et al. (21), and Whitehead et al. (11) reported MTX metabolism in bone marrow cells from patients with leukemia in both acute phase and remission. These investigators, however, did not use a purified bone marrow cell population. The bone marrow aspirate population is heterogeneous and contains myeloid cells at various stages of maturation, as well as erythroid precursors, lymphocytes, and monocytes. These cell populations may have different pharmacologic and metabolic properties. Thus, such a mixed cell population may not be optimal for examining drug metabolism by the specific cell population affected by MTX, namely the myeloid precursor pool. For this reason, purified immature MPCs were used in this study. The immune rosette technique allowed elimination of most mature granulocytes, monocytes, $\mathrm{T}$ and B lymphocytes, and erythroid precursors, and a much more homogeneous MPC population was obtained. Undifferentiated blasts were preferentially selected and accounted for $68 \% \pm 12 \%$ of the purified total cell population. These changes were associated with an $\sim 16$-fold increase in cloning efficiency in the CFU-C assay, indicating co-purification of the clonogenic myeloid precursor cells. These purification techniques allowed more precise examination of MTX metabolism in normal myeloid precursors, and may be useful in examining bone marrow metabolism of other drugs as well.

Table VI. MTX Inhibition of Colony Formation of HL-60 Cells

\begin{tabular}{lll}
\hline MTX concentration & $\begin{array}{l}\text { No. of cells after } 24-\mathrm{h} \\
\text { incubation with MTX }\end{array}$ & Colonies \\
\hline$\mu M$ & $\%$ control & $\%$ control \\
0 (control) & 100 & 100 \\
1 & $94.4 \pm 14.8$ & $3.0 \pm 0.5$ \\
10 & $96.8 \pm 2.7$ & $1.5 \pm 1.2$
\end{tabular}

Cells were incubated for $24 \mathrm{~h}$ in medium containing the indicated concentration of MTX, $10 \mu \mathrm{M}$ thymidine, and $10 \mu \mathrm{M}$ deoxyinosine. After counting the number of viable cells by trypan blue dye exclusion, cells were then washed and processed in a clonogenic assay using a methylcellulose semisolid system (30) containing $15 \%$ dialyzed FCS in drug- and rescue-free medium. The number of colonies in the control group was $201 \pm 19 / 10^{4}$ cells plated. Each value represents the mean \pm 1 SD of triplicate cultures.

\section{Acknowledgments}

We thank Dr. Thalia Papayannopoulou (University of Washington, Seattle) for providing an EP1 monoclonal antibody and Kathy Moore for preparation of the manuscript.

\section{References}

1. Chabner, B. A. 1982. Methotrexate. In Pharmacologic Principles of Cancer Treatment. B. A. Chabner, editor. W. B. Saunders Co., Philadelphia. 229-255.

2. Jolivet, J., K. H. Cowan, G. A. Curt, N. J. Clendeninn, and B. A. Chabner. 1983. The pharmacology and clinical use of methotrexate. N. Engl. J. Med. 309:1094-1104.

3. Covey, J. M. 1980. Polyglutamate derivatives of folic acid coenzymes and methotrexate. Life Sci. 26:665-678.

4. Baugh, C. M., C. L. Krumdieck, and M. G. Nair. 1973. Polygammaglutamyl metabolites of methotrexate. Biochem. Biophys. Res. Commun. 52:27-34.

5. Jacobs, S. A., C. J. Derr, and D. G. Johns. 1977. Accumulation of methotrexate diglutamate in human liver during methotrexate therapy. Biochem. Pharmacol. 26:2310-2313.

6. Whitehead, V. M., M. M. Perrault, and S. Stelcner. 1975. Tissuespecific synthesis of methotrexate polyglutamates in the rat. Cancer Res. 35:2985-2990.

7. Whitehead, V. M. 1977. Synthesis of methotrexate polyglutamates in L1210 murine leukemia cells. Cancer Res. 37:408-412.

8. Poser, R. G., F. M. Sirotnak, and P. L. Chello. 1981. Differential synthesis of methotrexate polyglutamates in normal proliferative and neoplastic mouse tissues in vivo. Cancer Res. 41:4441-4446.

9. Fry, D. W., L. A. Anderson, M. Borst, and I. D. Goldman. 1983. Analysis of the role of membrane transport and polyglutamation of methotrexate in gut and the Ehrlich tumor in vivo as factors in drug sensitivity and selectivity. Cancer Res. 43:1087-1092.

10. Rosenblatt, D. S., V. M. Whitehead, N. Vera, A. Pottier, M. Dupont, and M. J. Vuchich. 1978. Prolonged inhibition of DNA synthesis associated with the accumulation of methotrexate polyglutamates by cultured human cells. Mol. Pharmacol. 14:1143-1147.

11. Whitehead, V. M., and D. S. Rosenblatt. 1983. Methotrexate metabolism by bone marrow cells from patients with leukemia. In Folyl and Antifolyl Polyglutamates. D. Goldman, B. A. Chabner, and J. R. Bertino, editors. Plenum Press, New York. 287-303.

12. Goldman, I. D., N. S. Lichtenstein, and V. T. Oliverio. 1968. Carrier-mediated transport of the folic acid analogue methotrexate in the L1210 leukemia cell. J. Biol. Chem. 243:5007-5017.

13. Fry, D. W., J. C. Yalowich, and I. D. Goldman. 1982. Rapid formation of poly-gamma-glutamyl derivatives of methotrexate and 
their association with dihydrofolate reductase as assessed by high pressure liquid chromatography in the Ehrlich ascites tumor cell in vitro. J. Biol. Chem. 257:1890-1896.

14. Gewirtz, D. A., J. C. White, J. K. Randolph, and I. D. Goldman. 1980. Transport, binding, and polyglutamation of methotrexate in freshly isolated rat hepatocytes. Cancer Res. 40:573-578.

15. Galivan, J. 1980. Evidence for the cytotoxic activity of polyglutamate derivatives of methotrexate. Mol. Pharmacol. 17:105-110.

16. Balinska, M., Z. Nimec, and J. Galivan. 1982. Characteristics of methotrexate polyglutamate formation in cultured hepatic cells. Arch. Biochem. Biophys. 216:466-476.

17. Jolivet, J., and R. L. Schilsky. 1981. High-pressure liquid chromatography analysis of methotrexate polyglutamates in cultured human breast cancer cells. Biochem. Pharmacol. 30:1387-1390.

18. Jolivet, J., R. L. Schilsky, B. D. Bailey, J. C. Drake, and B. A. Chabner. 1982. Synthesis, retention, and biological activity of methotrexate polyglutamates in cultured human breast cancer cells. J. Clin. Invest. 70:351-360.

19. Jolivet, J., and B. A. Chabner. 1983. Intracellular pharmacokinetics of methotrexate polyglutamates in human breast cancer cells: Selective retention and less dissociable binding of $4-\mathrm{NH}_{2}-10-\mathrm{CH}_{3}-$ $\mathrm{PteGlu}_{4}$ and 5 to dihydrofolate reductase. J. Clin. Invest. 72:773-778.

20. Curt, G. A., J. Jolivet, B. D. Bailey, D. N. Carney, and B. A. Chabner. 1984. Synthesis and retention of methotrexate polyglutamates by human small-cell lung cancer. Biochem. Pharmacol. 33:1682-1685.

21. Fabre, I., G. Fabre, and I. D. Goldman. 1984. Polyglutamylation, an important element in methotrexate cytotoxicity and selectivity in tumor versus murine granulocytic progenitor cells in vitro. Cancer Res. 44:3190-3195.

22. Fry, D. W., L. A. Anderson, M. Borst, and I. D. Goldman. 1983. Analysis of the role of membrane transport and polyglutamation of methotrexate in the gut and the Ehrlich tumor in vivo as factors in drug sensitivity and selectivity. Cancer Res. 43:1087-1092.

23. Breitman, T. R., S. J. Collins, and B. R. Keene. 1980. Replacement of serum by insulin and transferrin supports growth and differentiation of the human promyelocytic cell line, HL-60. Exp. Cell Res. 126:494-498.

24. Todd, R. F., III, and S. F. Schlossman. 1984. Differentiation antigens on human monocytes and macrophages defined by monoclonal antibodies. In Mononuclear Phagocyte Biology. A. Volkman, editor. Marcel Dekk r, New York. In press.

25. Yokochi, T., M. Brice, P. S. Rabinovitch, T. Papayannopoulou, and G. Stamatoyannopoulos. 1984. Monoclonal antibodies detecting antigenic determinants with restricted expression on erythroid cells: from the erythroid committed progenitor level to the mature erythroblast. Blood. 63:1376-1384.

26. Koizumi, S., M. Yamagami, M. Miura, S. Horita, M. Sano, N. Ikuta, and N. Taniguchi. 1982. Expression of la-like antigens defined by monoclonal OKIal antibody on hemopoietic progenitor cells in cord blood: A comparison with human bone marrow. Blood. 60:10461049.

27. Koizumi, S., M. Yamagami, Y. Ueno, M. Miura, and N. Tanignchi. 1980. Resistance of human bone marrow $\mathrm{CFU}_{\mathrm{C}}$ to highdose methotrexate cytotoxicity. Exp. Hematol. 8:635-640.

28. Griffin, J. D., R. P. Beveridge, and S. F. Schlossman. 1982. Isolation of myeloid progenitor cells from peripheral blood of chronic myelogenous leukemia patients. Blood. 60:30-37.

29. Lowry, O. H., N. J. Rosenbrough, A. I. Farr, and R. I. Randall. 1951. Protein measurement with the folin phenol reagent. J. Biol. Chem. 193:265-275.

30. Pike, B. L., and W. A. Robinson. 1970. Human bone marrow colony growth in agar-gel. J. Cell Physiol. 76:77-84.

31. Bessho, M., K. Hirashima, H. Nomura, M. Ono, T. Okabe, N. Ohsawa, N. Nara, and H. Momoi. 1984. Effects on human bone marrow cells of colony-stimulating factors produced in large quantities from the conditioned medium of thyroid cancer cells. Acta Haematol. Jpn. In press.

32. Chabner, B. A., and R. C. Young. 1973. Threshold methotrexate concentration for in vitro inhibition of DNA synthesis in normal and tumorous target tissues. J. Clin. Invest. 52:1804-1811. 